ISSN 1991-8631

Original Paper

http://indexmedicus.afro.who.int

\title{
Vegetation and plant diversity pattern study of Central Eastern Niger grasslands
}

\author{
I. SOUMANA ${ }^{1 *}$, A. MAHAMANE ${ }^{1}$, Z. GANDOU ${ }^{2}$, J-M.K. AMBOUTA ${ }^{3}$ and \\ M. SAADOU ${ }^{1}$
}

\author{
${ }^{1}$ Laboratoire Garba Mounkaila, Faculté des Sciences, Université Abdou Moumouni de Niamey, Niger. \\ E-mails :smaiga15@yahoo.fr,ali_mahamane@yahoo.fr,saadou_mahamane@yahoo.fr \\ ${ }^{2}$ Facultés des Sciences Economiques et Juridiques, Université Abdou Moumouni de Niamey, Niger. \\ ${ }^{3}$ Faculté d'Agronomie, Université Abdou Moumouni de Niamey, Niger. E-mail : ambouta.karimou@yahoo.fr \\ *Corresponding author, E-mail: smaiga15@yahoo.fr
}

\begin{abstract}
Vegetation and plant diversity patterns of Central Eastern Niger grasslands were investigated following phytosociological methods. Vegetation data collected on 76 plots by using the Braun-Blanquet's (1932) coverabundance scale were analyzed through five multivariate analyses (TWINSPAN, NMS, DCA, ISA and MRPP) in order to distinguish and to describe plant communities. Alpha diversity ( $H^{\prime}, \mathrm{E}$ and $\mathrm{R}$ ) was also used to describe these communities. A total of 162 species belonging to 37 families and 104 genera were identified. Dominant families were the Poaceae (18\%), Leguminosae-Papilionoideae (8\%), Convolvulaceae (7\%) and Leguminosae-Caesalpinioideae (4\%). Life forms were dominated by Therophytes (59\%) and Phanerophytes (27\%), whereas the most prominent geoelements were of the Soudano-zambesians-saharo-sindians (33\%), Soudano-zambesians $(25 \%)$ and Guineo-congolian-soudano-zambesians $(25 \%)$ types. In total, five plant communities were identified on the basis of environmental gradients and species composition. The environmental parameters that favorably influence these plant distributions are topography, moisture, texture and land use (fallow, pasture). Importantly, each of these communities seems to correspond to a particular wildlife habitat. These habitats shelter their own species that may be seen as a keystone species.

() 2012 International Formulae Group. All rights reserved.
\end{abstract}

Keywords: Multivariate analysis, vegetation communities, characteristic species, Central East grassland, Niger.

\section{INTRODUCTION}

Rangelands are defined by the Society for Range Management (SRM) as lands characterized by self-propagating plant communities, predominately grasses, grasslike forbs, shrubs and dispersed trees. Vegetation of rangeland is essentially used to support livestock production and biodiversity conservation (Soumana, 2011). The context in which rangelands are viewed worldwide is rapidly changing (Natalie, 2000). Ranging, agriculture and climate change are the major factors of modifications. As an example, many types of Sahelian grasslands have been converted to croplands while the remaining areas have usually been overgrazed. Overgrazing may cause biodiversity losses which, in turn, may also have an impact on belowground ecosystem functions, including soil processes, structure and biota (Hiernaux 
et al., 1999; Manzano \& Navar, 2000, Su et al., 2005). This can greatly reduce rangeland productivity and induce deep changes in botanical composition towards poorer quality species (Comakli et al., 2008). However, vegetation patterns are not influenced by a single factor, but are rather resulting from a complex array of interacting factors, both biotic and abiotic, whose relative importance varies with spatial scale (Mutanga et al., 2004). In recent years, intensive studies concerning the effects of antropic actions and climate change on vegetation dynamics have been carried out in West Africa (Natta, 2003; Oumarou, 2003; Mahamne, 2005; Orthmann, 2005; Ouoba, 2006 ; Morou, 2010; Nacoulma, 2011 etc.) but very few have focused on its effect on sahelian rangelands (Boudet \& Duverger, 1961; Togola, 1982; Djiteye, 1984; Soumana, 2011). To better understand rangeland ecosystems, it is important to study the relationships between environmental factors and vegetation. Such the precise description of plant communities can greatly help in delimiting functional units of management and provides effective way to monitor grasslands (Cheng \& Nakamara, 2007). In addition, biophysical classifications may improve the accuracy of predicting such management-relevant characteristics as browse production and tree growth (DeVelice et al., 1999). In the present paper, BraunBlanquet and multivariate techniques (Twoway Indicator Species Analysis (TWINSPAN), Non-metric Multidimensional Scaling (NMS), detrended correspondence analysis (DCA), Indicator Species Analysis (ISA), Multi-Response Permutation Procedures (MRPP)), were used in combination to describe grasslands vegetation patterns and identify their relationships to environmental factors in sahelian grasslands.

\section{MATERIEL AND METHODS Study area}

The study was conducted in rangelands surrounding Bouné village $\left(13^{\circ} 05 \mathrm{E} \& 13^{\circ} 45\right.$ $\mathrm{N}$ ), district of Zinder, Niger (Figure 1), that lies within the Sahel Transition Zone (White, 1976). The climate of the region is typically a tropical arid (Figure 2) one, with annual mean precipitation and temperature being $341 \pm 115$

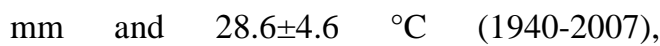
respectively. The soil texture of our study sites is sandy, with the exception of some depressions where it is made of sandy clay or sandy silt. These conditions provide a vegetation of steppe which is mainly used for livestock production. In Bouné steppe, the scattered woody shrubs are dominated by Acacia senegal (L.) Willd., Acacia tortilis (forsk.) Hayne subsp. Raddiana (Savi.) Brenan. and Balanites aegyptiaca (L.) Del. The herbaceous cover is dominated by Cenchrus biflorus Roxb., Brachiara xantoleuca (Schinz.) Stapf., Aristida mutabilis Trin. \& Rupr., Digitaria horizontalis Willd. and Schoenefeldia gracilis Kunth.

\section{Vegetation survey}

Plant and environment factors were recorded from the end of August and to the beginning of September 2008 when the sahelian herbs cover was at maximal development, with grasses and forbs easily identifiable. Stratified sampling with clustering was adopted in this study. The stratification was based on the topography of the pasture. Several plots of $20 \mathrm{~m} \times 50 \mathrm{~m}$ were placed on each topographic unit (dune, versant and depression). For each plot, GPS coordinates, type of land use, soil texture, geomorphology, biomass and floristic composition were recorded. Biomass was recorded by throwing randomly a $1 \mathrm{~m}^{2}$ wire into the plot; the standing grasses that fell within the wire were also clipped and measured. Eight to ten wires were cut within each plot and biomass of each wire was sacked, dried and weighted. Floristic composition of each plot was recorded using the Braun-Blanquet's cover-abundance scale. Plant communities were then classified following their species contents (BraunBlanquet, 1932).

\section{Data analysis}

Five multivariate analyses were used to describe and describe plants assemblages on the basis of floristic composition and plants abundance. Firstly, Two-way Indicator Species Analysis (TWINSPAN; Hill, 1979b) was implemented using the default pseudospecies cut levels $(0 \%, 2 \%, 5 \%, 10 \%, 20 \%$ 
cover) in order to discriminate groups based on floristic differences. The plants communities were identified at the third level of the dendrogram $(25 \%)$. This classification produced a first approximation of a hierarchical classification of stands that reflects floristic similarity.

Second, an indirect gradient multivariate ordination method, i.e. Nonmetric Multidimensional Scaling (NMS; McCune \& Grace, 2002), was performed to examine relationships among plots as well as among plant communities. NMS is an iterative optimization ordination procedure that allows one to visualize analytical purposes into fewer dimensions. It is based on the Autopilot's Relative Euclidean measure of similarity. For the purpose of the present study, NMS was complemented by the use of an eigenvector ordination based on Detrended Correspondence Analysis (DCA) (Hill, 1979a) to observe patterns of vegetation along the topographic gradient. DCA provides eigenvalues that can be used to estimate gradient widths, something that is not feasible with NMS. Fourth, Indicator Species Analysis (ISA) (Dufrêne \& Legendre, 1997) was used to identify which species were characteristic for each community. It combines relative abundances and frequencies to calculate the indicator values (IV) of the species, ISA provides IV for each species of each group that are tested for statistical significance using Monte Carlo's randomization test. Among the most characteristic species, two species (one woody and one grass) with high IV, low Pvalue and which are known as highly palatable for livestock, were used to name plant communities. Fifth, nonparametric test, Multi-Response Permutation Procedures (MRPP; McCune \& Grace, 2002 was used for testing species group differences. MRPP is a non-parametric multivariate procedure that tests between species composition of two or more a priori groups. All these analyses were implemented using PC-ORD v.5.0 (McCune \& Grace, 2002).

Finally, alpha diversity based on Shannon-Weaver (1949) index (H'), evenness (E) of Piélou (1966) as well as floristic richness (i.e. number of species per community; R) was calculated for each community.

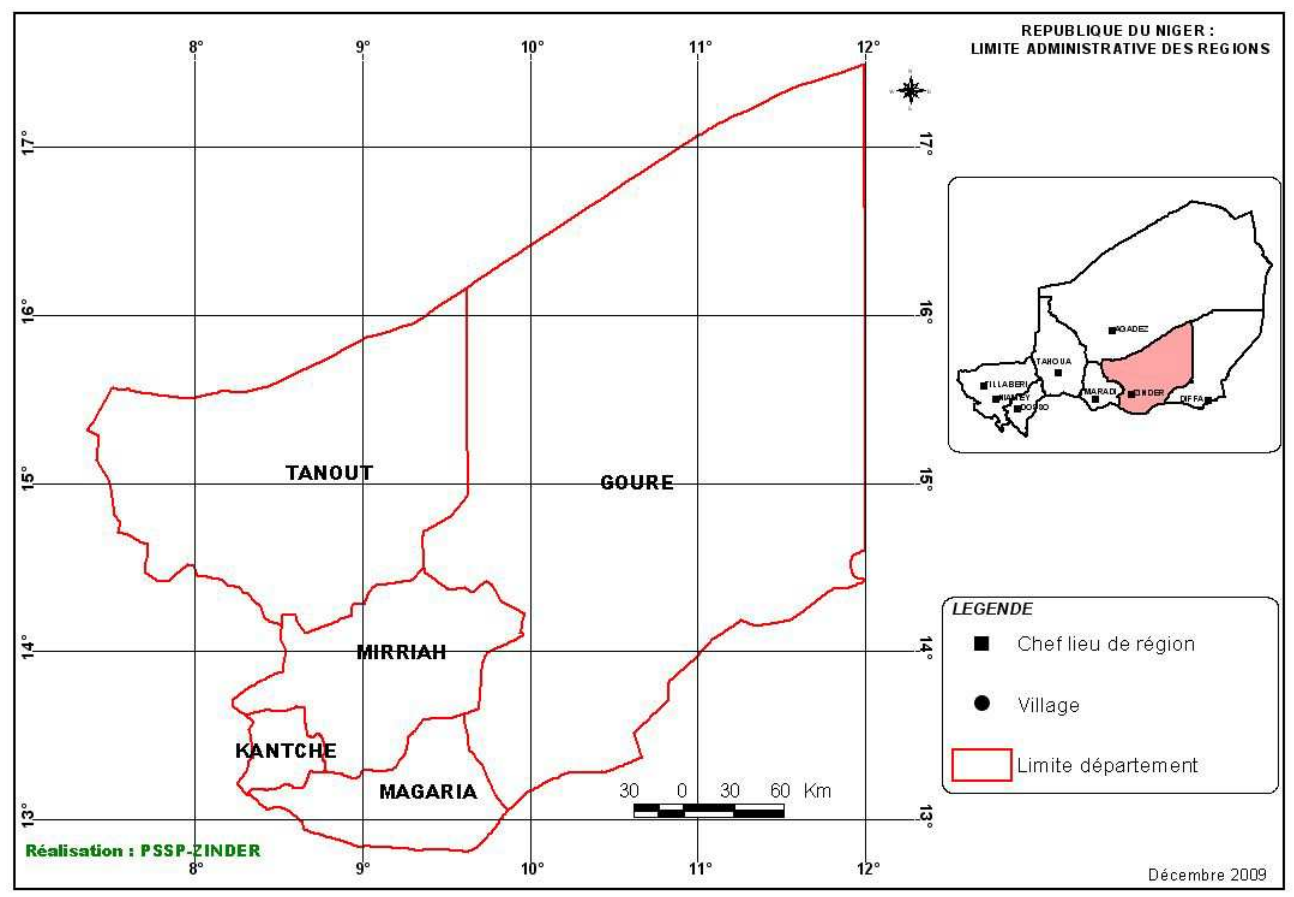

Figure 1 : Study area. 


\section{RESULTS}

\section{Floristic patterns}

One hundred and sixty two (162) species were recorded for a total of 76 plots. Species richness per plot ranged between 17 and 42, and averaged 28. Most of the species were Soudano-zambesians-saharo-sindians (SZ-Sah-S; 33\%), Soudano-zambesians (SZ; $25 \%$ and Guineo-congolian-soudanozambesians (GC-SZ; 25\%) (see Figure 2). Among these species, life forms were dominated by Therophytes (Th; 59\%) and Phanerophytes ( $\mathrm{MsPh}, \mathrm{NnPh}, \mathrm{LMcPh} ; 27 \%$ ). Chamephytes $(\mathrm{CH})$, Hemicryptophytes $(\mathrm{H})$, Hygrophytes (Hy) and Geophytes (Ge) represented $6 \%, 3 \%, 3 \%$ and $2 \%$ of the species, respectively (Figure 3). In total, 104 genera and 37 families were represented: Poaceae (18\%), Leguminosae-Papilionoideae (8\%), Convolvulaceae (7\%), LeguminosaeCaesalpinioideae (4\%), LeguminosaeMimosoideae (4\%), Euphorbiaceae (4\%), Cyperaceae (4\%), Malvaceae (4\%), Cucurbitaceae (3\%), Capparaceae (3\%), Rubiaceae (3\%), Solanaceae (2\%), Solanaceae (2\%), Commelinaceae (2\%), Combretaceae (2\%), Borraginaceae (2\%), Asteraceae (2\%), Asclepiadaceae (2\%), Aizoaceae (2\%), Acanthaceae (2\%), Anacardiaceae (1\%), Anonaceae (1\%), Arecaceae(1\%), Balanitaceae (1\%), Bombacaceae (1\%), Burseraceae (1\%), Caryophyllaceae (1\%), Lamiaceae (1\%), Loranthaceae (1\%), Menispermaceae (1\%), Pedaliaceae (1\%), Portulacaceae (1\%), Rhamnaceae (1\%), Sterculiaceae (1\%) and Zygophyllaceae (1\%). Among the 162 species, 133 species were herbaceous, while the others were woody species. Their respective cover represented $63 \%$ and $27 \%$. The herbaceous layer was dominated by Digitaria horizontalis Willd. (11\%), Dactyloctenium aegyptium (L.) Willd. (5\%), Brachiaria xantholeuca (Schinz.) Stapf. (5\%), Amaranthus spinosus L. (5\%), Zornia glochidiata Reichb. Ex DC (4\%). The woody layer was dominated by Acacia tortilis (forsk.) Hayne subsp. Raddiana (Savi.) Brenan. (8\%), Acacia senegal (L.) Willd. (6\%), Acacia seyal Del (2\%) and Balanites aegyptiaca (L.) Del. (2\%).

\section{Vegetation patterns}

TWINSPAN splitted the 162 species and 76 plots into 5 vegetation communities (Figure 4). These communities as well as environmental variables were graphically projected using NMS (Figure 5), and DCA made the gradient length of the different NMS-produced axes interpretable (Figure 6). Axis 1 (gradient length $=3.334$ ) discriminated plots from sandy dune at its outset and plots from silt depressions at its upper storey, thus reflecting the underlying moisture and soil texture gradients. Axis 2 (gradient length = 2.41) grouped plots from dune at its lower storey, and plots from peneplain at its upper one. Correlations of axis2 confirmed the existence of a topographic gradient among vegetation features (Table 1). The environmental variables which discriminated these 5 vegetation communities strongly correlate with NMS axes (Table 1). Monte Carlo's randomization test based on the matrixes of field and environmental data also showed that the variations of the vegetation communities were strongly correlated with the environmental variables $(P=0.002)$,. MultiResponse Permutation Procedures (MRPP) based on the species and the five groups confirmed the highly significant difference between the taxonomic composition of the five plant communities $(T=-38 ; A=0.2$; $\mathrm{P}<0.000)$. Moreover the strong chancecorrected within-group agreement $(A)$ and test statistic $(T)$ reveal that the five groups occupies different regions of the species space and confirm spatial heterogeneity of the grassland. The average within-group agreement distance showed that the five groups had relatively high dispersions, with an 
average distance of between 0.72 and 93 . For each community as identified here above, characteristic species could be identified which indicate particular ecological conditions (Table 2). As such, among the 162 species recorded, Indicator Species Analysis (ISA) provided 75 characteristic species with various IV and P-values ranges (Table 2). The number of characteristic species was variable depending on the community considered (Table 3). For each community, two characteristic species with strong IV value and low P-value were considered as representative and so used to name their community.

High levels of floristic richness (R), alpha diversity (H') and Evenness of Piélou (E) were found (Table 3). Groups communities 2 and 3 have the highest R (103 and 99, respectively), the highest H' (4.21 and 4.58, respectively; Table 3) whereas the highest $\mathrm{E}$ values were recorded in groups 3 and 1 .

\section{Phytosociological description of each community}

Group 1: Leptadenia pyrotechnica Cyperus conglomeratus community (Table 3)

This community was restricted to the fixed dunes of the area, near the village where animal pressure was high. In total, 54 plant species were collected in 13 plots. Within each plot, 18-31 species were found species with an average number of species of $27 \pm 3$. The number of characteristic species reaches 20. The soil was typically sandy.

Group 2: Acacia tortilis (forsk.) Hayne subsp. Raddiana -Achyrantes aspera community (Table 4)

It was established on sandy plain where nomads and their livestock use to settle during the rainy season. A total of 103 species were recorded in 13 plots, with an average per plot of $31 \pm 6$ (range 22-42). Eleven indicator species were typical of this assemblage. Seeds dispersed by livestock may explain the high species richness in this community.

Group 3: Balanites aegyptiacaBrachiaria ramosa community (Table 5)

Group 3 was also represented also by 13 plots. This community was located in the depressions which are sometimes temporally flooded. In these depressions, shrubs of Balanites aegyptiaca (L.), Del. Acacia senegal (L.) Willd., Acacia seyal Del. form small thickets that offer specific microclimates. The soil is made of sandy-silt or sandy-clay. Ninety nine (99) species ranged from 25-40 were recorded with a mean value of $33 \pm 5$ (ecartype) in which twenty one (21) species were specifically characteristic of this community.

Group 4: Faidherbia albida-Cassia mimosoides community (Table 6)

This community was represented by 17 and was established on fallow lands used by livestock owners for ranging. These fallows lie on sandy plains that are also used for cropping. The total number of species recorded was 88, ranged from 23-35 with a mean number of $28 \pm 3$ in which 15 characteristic species contributed strongly in the formation of this community.

Group 5: Sclerocarya birreaBrachiaria xantholeuca community (Table 7)

This community was located within the sandy plain that was designed by the municipality only for livestock grazing and browsing. The aim of this restrictive policy is to support livestock production. A total of 80 species were collected in 20 stands. In each stand, the number of species ranged between 17-31 with an average number of $25 \pm 3$. Among them, 7 appeared characteristic for this particular community. 


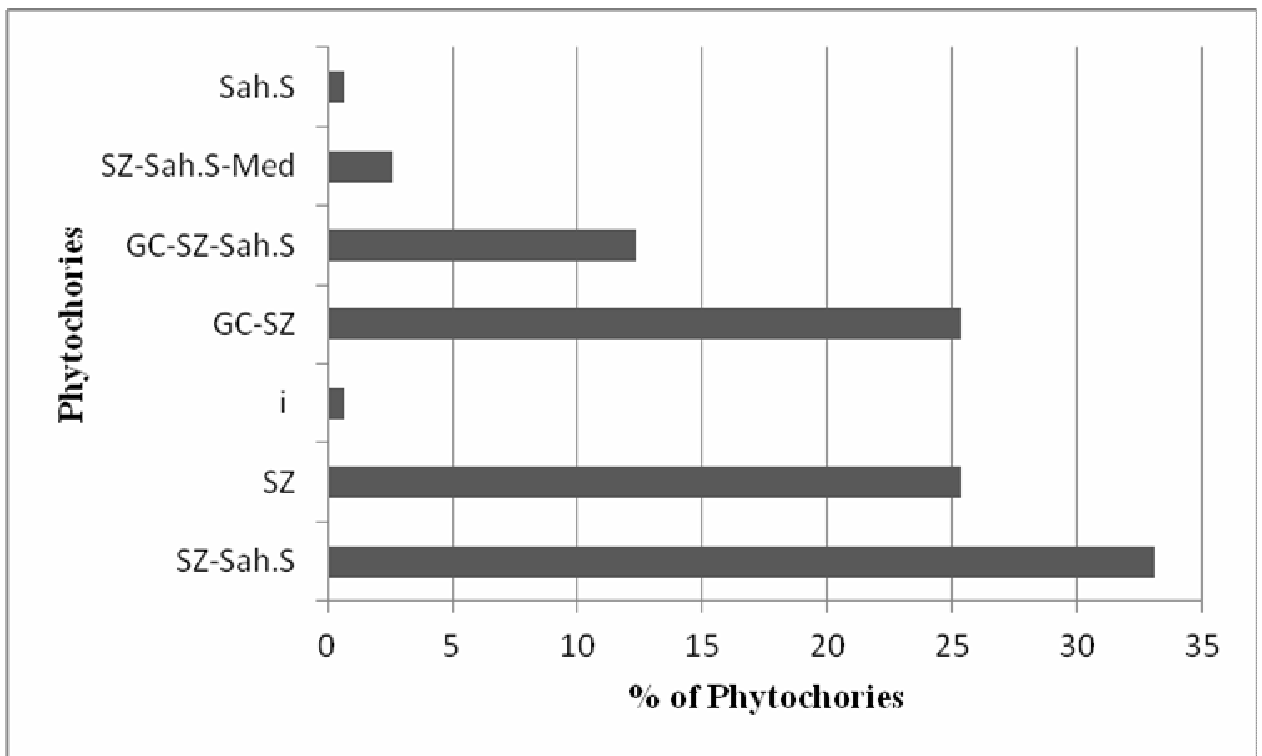

Figure 2 : Phytogeographic spectrum of Central Eastern Niger grasslands.

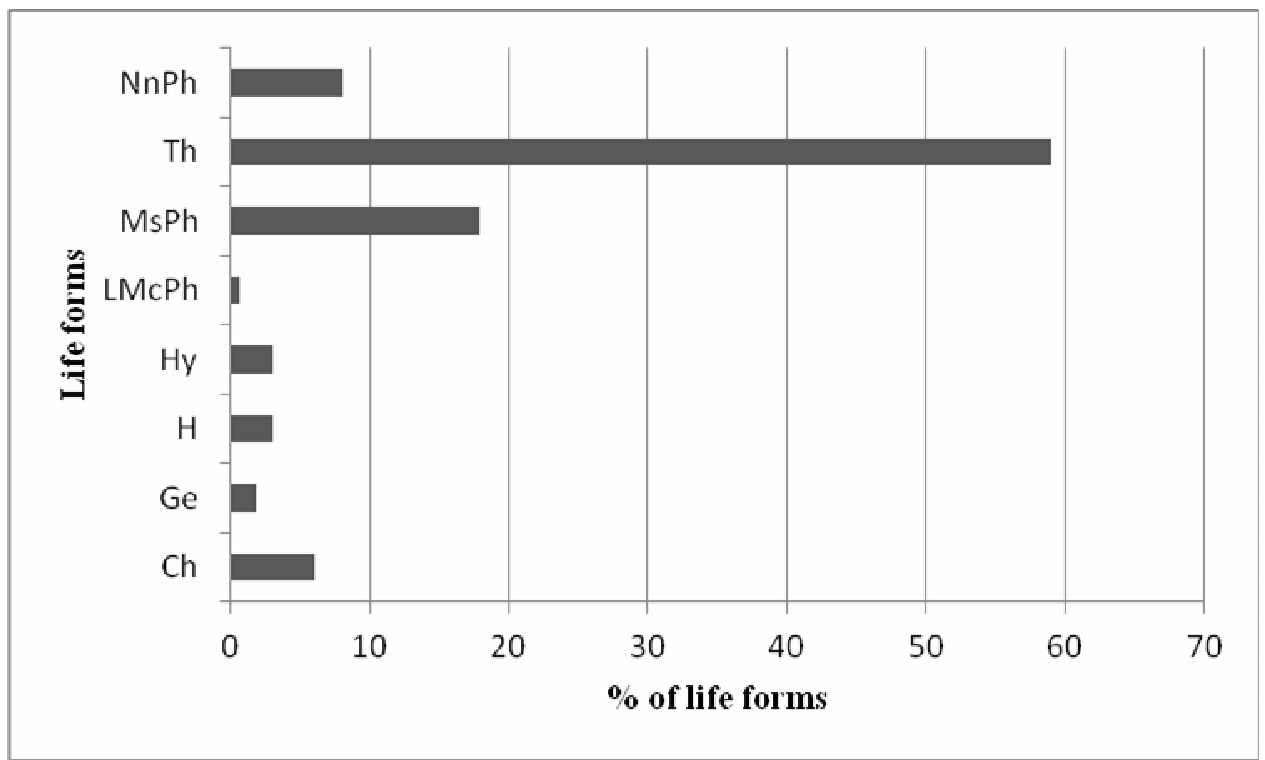

Figure 3: life forms spectrum of Central Eastern Niger grasslands. 


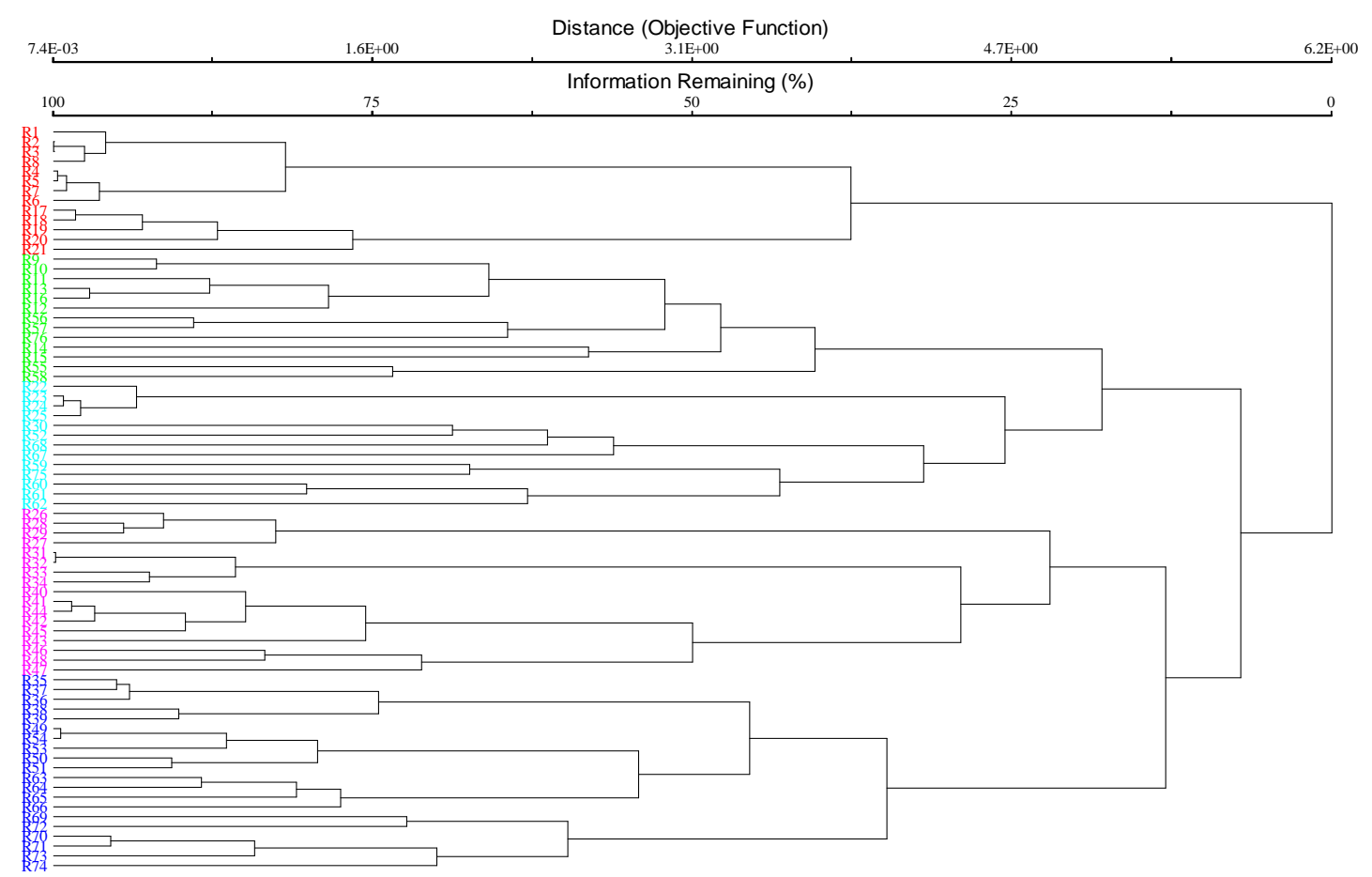

Figure 4: Classification of the species abundance/dominance data matrix utilizing Two-Way Indicator Species Analysis (TWINSPAN).

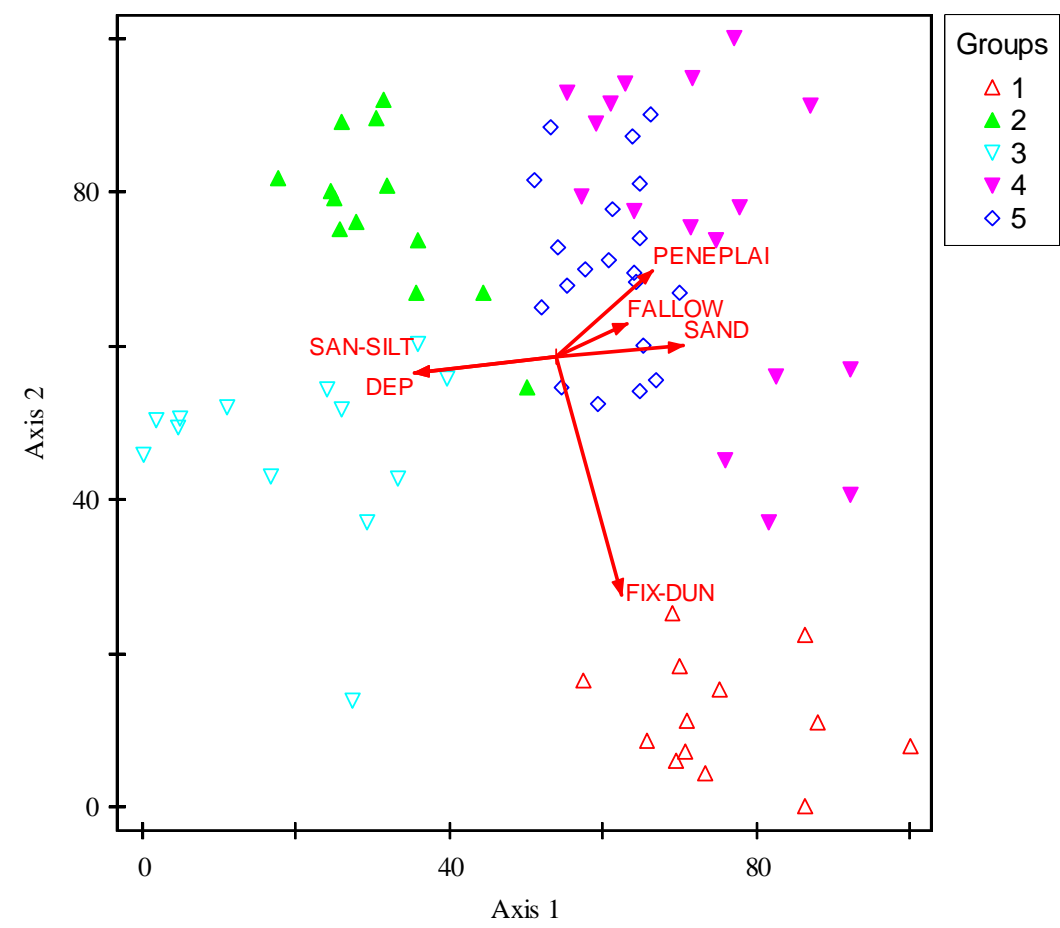

Figure 5: Ordination by Nonmetric Multidimensional Scaling (NMS) of 76 surveyed stands of Central Eastern Niger grassland vegetation. Cumulative variance provided by the three axes was $\mathrm{r}^{2}=0.80(0.16$, 0.34 and 0.30 for axes 1,2 and 3 , respectively. 


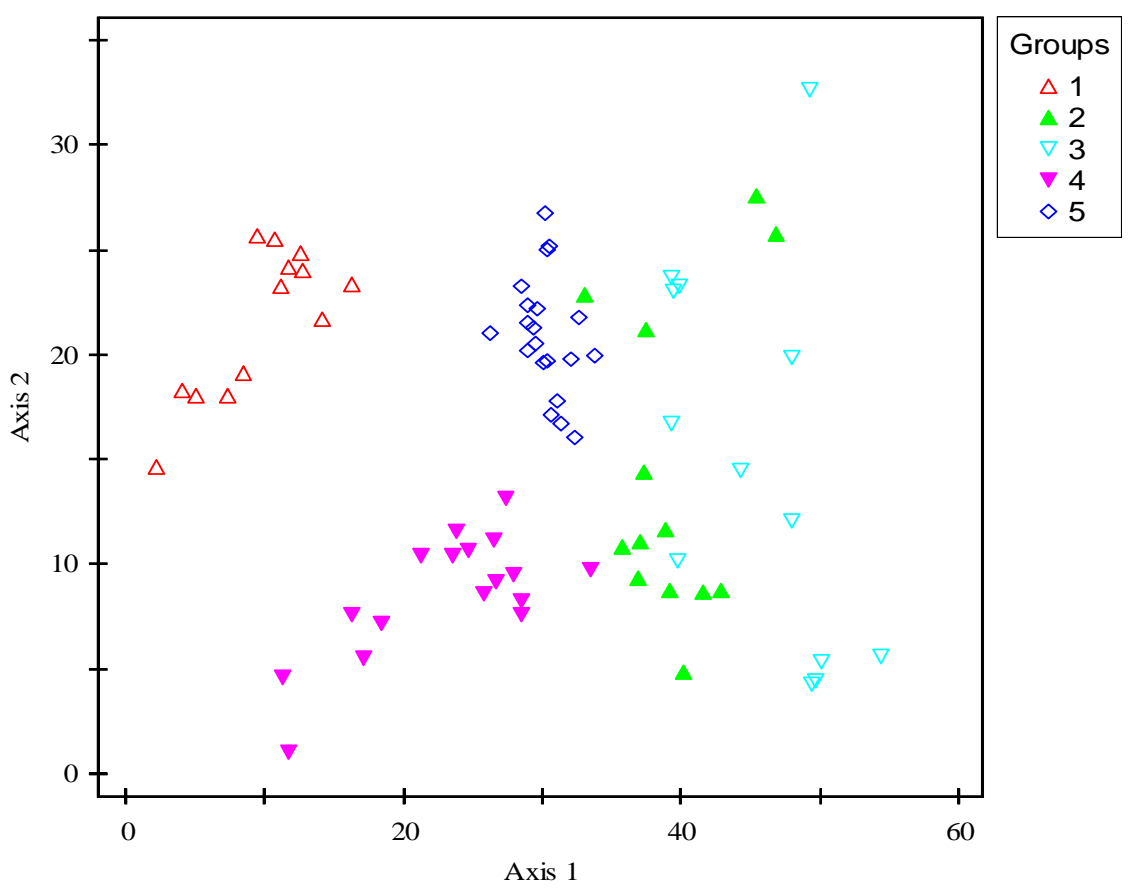

Figure 6: Ordination by detrended correspondence analysis (DCA) of 76 surveyed stands of Central Eastern Niger grassland vegetation. Eigenvalues of axes 1 and 2 were 0.41 and 0.23 , respectively.

Table 1 : Correlations of Pearson $(r)$ and Percent of variance explained (correlations of Kendall = $\mathrm{r}^{2}$ ) by environmental variables of NMS axes 1 and 2 on the Central Eastern Niger grassland vegetation.

\begin{tabular}{lcccr}
\hline & \multicolumn{2}{c}{ Axis 1 } & \multicolumn{2}{c}{ Axis 2 } \\
\hline Peneplain & $\mathbf{R}$ & $\mathbf{r}^{\mathbf{2}}$ & $\mathbf{r}$ & $\mathbf{r}^{\mathbf{2}}$ \\
Fallow & 0.50 & 0.25 & 0.47 & 0.22 \\
Fix-dune & 0.43 & 0.18 & 0.29 & 0.09 \\
Sand & 0.41 & 0.17 & 0.79 & 0.62 \\
Depression & 0.58 & 0.33 & 0.17 & 0.03 \\
Sandy-silt & -0.61 & 0.37 & -0.21 & 0.04 \\
\hline
\end{tabular}


Table 2: Among indicator species provided by IVA, only 75 species which have high value of IV and low $\mathrm{P}$-value $(\mathrm{P}<0.05)$ were recorded for each group.

\begin{tabular}{|c|c|c|c|}
\hline Species & Groups & IV & P-values \\
\hline Leptadenia pyrotechnica (Forssk.) Decne. & 1 & 52 & 0.0002 \\
\hline Cyperus conglomeratus Rottb. & 1 & 85 & 0.0002 \\
\hline Limeum viscosum (Gay.) Fenzl. & 1 & 17 & 0.04 \\
\hline Limeum pterocarpum (Gay) Heimer & 1 & 23 & 0.01 \\
\hline Ipomoea kotschyana Hochst. ex. Choisy. & 1 & 22 & 0.02 \\
\hline Phyllanthus pentandrus Schum. et Thonn. & 1 & 69 & 0.0002 \\
\hline Tribulus terrestris $\mathrm{L}$. & 1 & 31 & 0.002 \\
\hline Sesamum alatum Thon. & 1 & 23 & 0.02 \\
\hline Ipomoea pes-tigridis $\mathrm{L}$. & 1 & 21 & 0.04 \\
\hline Ipomoea coscinosperma Hochst. ex Choisy. & 1 & 33 & 0.001 \\
\hline Gisekia pharnacioides $\mathrm{L}$. & 1 & 47 & 0.0002 \\
\hline Gynandropsis (cleome) gynandra (L.) Briq. & 1 & 76 & 0.0002 \\
\hline Cyperus esculentus L. = Pycreus exculentus (L.) Hayek. & 1 & 55 & 0.0002 \\
\hline Commelina forskoalei Vahl. & 1 & 37 & 0.0002 \\
\hline Citrillus lanatus (Thunb.) Matsumara et Nakai & 1 & 54 & 0.0002 \\
\hline Citrillus colocynthis (L.) Schrad. & 1 & 46 & 0.0004 \\
\hline Amaranthus spinosus L. & 1 & 40 & 0.0002 \\
\hline Andropogon gayanus Kunth. & 1 & 65 & 0.0002 \\
\hline Aristida sieberiana Trin. $=$ A. pallida Steud. & 1 & 100 & 0.0002 \\
\hline Spermacoce scabra (S. et Th.) K. Schum. & 1 & 50 & 0.0002 \\
\hline Cyperus rotundus $\mathrm{L}$. & 1 & 46 & 0.0002 \\
\hline Acacia raddiana Savi. & 2 & 43 & 0.0002 \\
\hline Acanthospermum hispidum DC. & 2 & 52 & 0.0002 \\
\hline Acacia senegal (L.) Willd. & 2 & 47 & 0.0002 \\
\hline Acacia seyal Del. & 2 & 49 & 0.0002 \\
\hline Achyrantes aspera $\mathrm{L}$. & 2 & 26 & 0.0002 \\
\hline Adansonia digitata $\mathrm{L}$ & 2 & 20 & 0.01 \\
\hline Spermacoce chaetocephala DC & 2 & 61 & 0.0002 \\
\hline Heliotropium bacciferum Linn. & 2 & 40 & 0.0002 \\
\hline Cassia tora $\mathrm{L}$. & 2 & 24 & 0.01 \\
\hline Evolvulus alsinoides (L.) L. & 2 & 16 & 0.04 \\
\hline Pavonia triloba Guill. Et Perr. & 2 & 31 & 0.001 \\
\hline Balanites aegyptiaca (L.) Del. & 3 & 57 & 0.0002 \\
\hline Brachiaria ramosa (L.) Stapf. & 3 & 55 & 0.0002 \\
\hline Brachiaria lata (Schum.) C.E. Hubbard. & 3 & 41 & 0.0002 \\
\hline Corchorus olitorius L. & 3 & 29 & 0.003 \\
\hline Cordia sinensis Lam. & 3 & 27 & 0.002 \\
\hline Echinochloa colona (L.) Link. & 3 & 31 & 0.0012 \\
\hline Eragrostis pilosa (L.) P. Beauv. & 3 & 39 & 0.0002 \\
\hline Panicum laetum Kunth. & 3 & 55 & 0.0002 \\
\hline \multicolumn{4}{|l|}{ Panicum subalbidum Kunth. $=$ P. glabescens $=$ Panicum } \\
\hline longijubatum Stapf. & 3 & 46 & 0.0002 \\
\hline Sida ovata Forsk. & 3 & 41 & 0.0002 \\
\hline Stylosanthes mисronata Willd. & 3 & 39 & 0.0004 \\
\hline
\end{tabular}


Bidens biternata (Lour.) Merrill. et Sherff. = B. pilosa L.

0.001

Cyperus bulbosus Vahl.

0.01

Blumea aurita (L.) DC.

0.0012

Hibiscus hasirikus Berh.

0.002

Hyphaene thebaica Mart.

0.01

indigofera tinctoria $\mathrm{L}$.

Ipomoea eriocarpa $\mathrm{R} . \mathrm{Br}$.

0.01

Ipomoea stolonifera (Cyrill.) J. F. Gmel

0.002

Tephrosia jinjinea

0.002

Ziziphus mauritiana Lam.

0.03

0.02

Faidherbia albida (Del.) A. Chev.

.0002

Cassia mimosoides L.

Eragrostis tremula Steud.

0.0002

0.0002

0.01

Leptadenia hastata (Pers.) Decne.

0.04

Aristida stipoides Lam.

Calotropis procera (Ait.) R. Br.

Fimbristylis hispidula (Vahl.) Kunth.subsp. Hispidula

0.04

Indigofera aspera Perr.

Ipomoea vagans Bak.

Jacquemontia tamnifolia (L.) Griseb.

Momordica balsamina L.

Pergularia tomentosa $\mathrm{L}$.

0.001

0.0002

0.03

0.0002

0.03

0.02

0.02

Annona senegalensis Pers.

$\begin{array}{lllr}\text { Aristida mutabilis Trin. et Rupr. = A. meccana Hochst. ex. Trin Rpr. } & 4 & 50 & 0.0002 \\ \text { Tephrosia purpurea (L.) Pers. Ssp. Leptostachya (DC.) Brum. } & 4 & 24 & 0.004\end{array}$

$\begin{array}{llll}\text { Sclerocarya birrea (A. Rich.) Hochst. } & 5 & 68 & 0.0008\end{array}$

Digitaria horizontalis Willd. $\quad 5 \quad 33 \quad 0.0002$

Brachiaria xantholeuca (Schinz.) Stapf.=Brachiaria orthostachys $\quad 5 \quad 30 \quad 0.005$

Mitracarpus villosus (Sw.) DC. = M. scaber Zucc. $\quad 5 \quad 42 \quad 0.0002$

Solanum incanum L. $\quad 5 \quad 37 \quad 0.0004$

$\begin{array}{llll}\text { Waltheria indica L. } & 5 & 40 & 0.0002\end{array}$

Zornia glochidiata Reichb. Ex DC. $\quad 5 \quad 37 \quad 0.003$

Table 3: Shannon-Weaver index (H'), Evenness of Piélou (E), floristic richness (R), number of Indicator species (IS) of each community.

\begin{tabular}{lcccr}
\hline & H' $^{\prime}$ & E & R & IS \\
\hline Group 5 & 4.01 & 0.63 & 80 & 7 \\
Group 4 & 4.09 & 0.63 & 88 & 15 \\
Group 3 & 4.58 & 0.69 & 99 & 21 \\
Group 2 & 4.21 & 0.63 & 103 & 11 \\
Group 1 & 3.71 & 0.64 & 54 & 20 \\
\hline
\end{tabular}




\section{DISCUSSION}

Species richness

The number of species $(n=162)$ collected in the grassland of Bouné, Niger, was similar to the one obtained in Hodh's grassland (Mauritania), $(\mathrm{n}=161)$ (Boudet \& Duverger, 1961), but lower than the one noted in Kaarta (Mali), $(\mathrm{n}=230)$ (Togola, 1982) and in Niono (Mali), $(n=227$ species) (Djiteye, 1984). However, the higher species richness of Kaarta and Niono is most probably due to the fact that floristic data were collected in both communal exclosure pasture and fenced range.

All these grasslands were dominated by Thérophytes life forms (59\% in Bouné ; 61\% in Hodh; $67 \%$ in Niono; see references above and this study) and by the family of Poaceae (18\% in Bouné; $21 \%$ in Kaarta), that are both characteristic elements of arid zones. Abundance of SZ-Sah-S geoelements corroborates the arid pattern of Central Eastern Niger grasslands. Most of the species mentioned in this study were recorded in the three orders (Boudet \& Duverger, 1961; Togola, 1982; Djiteye, 1984). During the previous survey performed in 1961 by Boudet \& Duverger in Hodh, a similar number of species than the one presented here was found. This similarity suggests that biodiversity may have been maintained in grasslands within the last three decades despite the climate change, grassland conversion to cropland and overgrazing. In fact, these results emphasize the importance of the conservation value of communal grasslands.

\section{Plant communities}

Multivariate's analyses of field data, plant species as well as environmental variables are considered as valuable and powerful methods to discriminate between ecological communities (McCune \& Grace, 2002). Using such analyses, we here identified 5 communities in Central Eastern Niger grasslands. Environmental gradient which may favorably influence these plant distributions are: topography, moisture, texture and land use (fallow, pasture). Moreover these environmental factors may be the responsible of floristic and vegetation patterns, and diversity of wildlife habitat of grassland. Anyway plant species and vegetation communities are known to display distribution patterns that are sometimes correlated to environmental gradients (Kershaw \& Looney 1985). Such associations enhance the conservation value of grasslands. Each plant community is characterized by its own specific ecological conditions and indicator species which contribute strongly to the maintaining of communities. Moreover, they may be seen as keystone species sensu Robert (1969). Extinction or large fluctuation in abundance of keystone species may seriously affect other species and lead to, or at least accelerate the extinction of the whole community (Jordan, 2006). Furthermore, these species can be used to analyze trends of vegetation and their underlying environmental variables. Indicator species and environmental variables may provide an accurate indicator to assess plant assemblage conditions. In particular, characteristic species frequency and the degree of fragmentation of the habitat may provide valuable tools to monitor so to manage plant community and their associated ecosystems.

Among the five communities identified in Central Eastern Niger, the Acacia tortilis (forsk.) Hayne subsp. Raddiana -Achyrantes aspera community from highly grazed areas, and the Balanites aegyptiaca- Brachiaria ramosa community from floodable depressions were found to be the richest communities (103 and 99 species, respectively). The Leptadenia pyrotechnica Cyperus conglomeratus community (54 species), characteristic of the sandy dunes was the poorest community. The two other communities, from fallow lands and natural pasturages, gathered 88 and 80 species, respectively. This gradual trend of species richness may be the consequence of seed dispersion by animals (Timothy, 2007), soil 
properties on water availability or on the redistribution of water between landforms and degradation grade (Wondzell et al., 1997). Indeed, seed dispersal via ingestion then defecation by herbivores (endozoochory) may play an important role in structuring plant communities in grasslands (Bakker et al., 2007). Such distribution of water base on geomorphology is fundamental to sustain vegetation structure in drylands (Ludwig et al., 2005). The efficient redistribution of water is accompanied by sediments and nutriment and allows for higher net primary productivity (Saco et al., 2007). For instance, on dunes, lower specific richness may be explained by a high degradation of vegetation. In depressions, the slope and the stream may help in concentrating moisture and nutriment that are favorable to the establishment of particular vegetation (Yimer et al., 2006), although flooding is known to cause a decrease in the number of species in wetlands (Laitinen et al., 2007).

\section{Conclusion}

Sahelian grasslands showed different vegetation types in the present study. Geomorphology, landuse and soil properties are the important factors in controlling plant diversity and vegetation pattern in sahelian grasslands. They were found to be more relevant to explain the heterogeneity and the biodiversity of sahelian grasslands. Communities from highly grazed and flooded depressions were found to be the richest and the strongest diversity communities. Excess of anthropogenic disturbances like overgrazing or converting rangeland to cropland for example, may strongly decrease biodiversity by negatively impacting rare characteristic species.

\section{ACKNOWLEDGMENTS}

The authors express their sincere appreciation to the Agence Francaise de Développement, the project for Understanding and combating desertification to mitigate its impact on ecosystem services (UNDESERT) and the Centre National de Suivi Ecologique du Niger (CNSE) for logistic and financial support to this study.

\section{REFERENCES}

Amezaga I, Mendarte S, Albizu I, Besga G, Garbisu C, Onaindia M. 2004. Grazing Intensity, Aspect, and Slope Effects on Limestone Grassland Structure. J. Range Manage, 57: 606-612.

Bakker JP, Ga'lvez BL, Mouissie A M. 2008. Dispersal by cattle of salt-marsh \& dune species into salt-marsh and dune communities. Plant Ecol., 197: 43-54.

Barry JP, Boudet G, Coulibaly AM, Leprun JC, Maniere R. 1983. Etude des

Potentialités Pastorales et de leur Evolution en Milieu Sahélien au Mali. Ed. ORSTOM : 115 pp.

Boudet G, Duverger E. 1961. Etude des pâturages naturels sahéliens: le Hodh(Mauritanie). Rev. El. Méd. Vét. Pays Trop., 161.

Braun-Blanquet J. 1932. Plant Sociology. The Study of Plant Communities. Ed. McGray Hill: New York, London; 439.

Cheng Y, Nakamura T. 2007. Phytosociological study of steppe vegetation in east Kazakhstan. Grassland Science, 53: 172-180.

Comakli B, Dafici M, Koc A. 2008. The Effects of Traditional Grazing Practices on Upland (Yayla) Rangeland Vegetation \& Forage Quality. Turk. J. Agric., 32: 259-265.

DeVelice RL, Hubbard CJ, Boggs K, Boudreau S, Potkin, M, Boucher T, Wertheim C. 1999. Plant community types of the Chugach National Forest: southcentral Alaska. USDA Forest Service, Chugach National Forest, Alaska Region Technical Publication R10-TP-76. Anchorage, AK. 375 p.

Djiteye M. 1984. Composition, structure et production des communautés végétales sahéliennes: Application à la région de Niono (Mali). Thèse de Doctorat de 
l'Université de Paris-sud, centre d'Orsay, p. 150.

Dufrêne M, Legendre P. 1997. Species assemblages and indicators species: the need for a flexible asymmetrical approach. Ecological Monographs, 67: 345-366.

Hill MO. 1979a. TWINSPAN - A FORTRAN program for arranging multivariate data in an Ordered Two-Way table by classification of the individuals and attributes. Ecology and systematic, Cornell University, Ithaca, New York 14850, USA.

Hill MO. 1979b. DECORANA - A FORTRAN program for detrended correspondence analysis and reciprocal averaging ecology and systematics. Cornell University, Ithaca, New York 14850, USA.

Hiernaux P, Bielders CL, Valentin C, Bationo A, Ferna'ndez-Rivera S. 1999. Effects of livestock grazing on physical and chemical properties of sandy soils in Sahelian rangelands. J. Rid Environ., 41: 231-245.

Jordan F, Liu W-C, Davis AJ. 2006. Topological keystone species: measures of positional importance in food webs. Oikos, 112: 535-546.

Kershaw KA, Looney JHH. 1985. Quantitative and Dynamic Plant Ecology (3rd edn). Edward Arnold: Australia.

Laitinen J, Tahvanianen T, Rehell S, Oksanen J. 2007. Vegetation ecology and flooding dynamic of Boreal aro wetlands. Ann. Bot. Fennici., 44: 359-375.

Ludwig JA, Wilcox BP, Breshears DD, Tongway DJ, Imeson AC. 2005. Vegetation patches and runoff-erosion as interacting ecohydrological processes in semiarid. Landscapes Ecology, 86(2), 288-297.

Mahamane A. 2005. Etudes floristique, phytosociologie et phytogéographique de la végétation du Parc Régional du W du Niger. Thèse d'Etat, Univ. Libre de Bruxelles, p. 497.
Manzano MG, Navar J. 2000. Processes of desertification by goats overgrazing in the Tamaulipan thrnscrub (matorral) in northeastern Mexico. J. Arid Environ., 44: 117.

McCune B, Grace JB. 2002. Analysis of Ecological Communities. Gleneden Beach, Oregon: MJM Software Design, $300 \mathrm{p}$.

Morou B. 2010. Impacts de l'occupation des sols sur l'habitat de la girafe au Niger et enjeux pour la sauvegarde du dernier troupeau de girafes de l'Afrique de l'Ouest. Thèse de doctorat, Université de Niamey, p. 198.

Mutanga O, Herbert HT, Andrew KS, Van Wieren S, Huizing H, Grant R, Peel M, Biggs H. 2004. Explaining grass-nutrient patterns in a savanna rangeland of southern Africa. Journal of Biogeography, 31: 819-829.

Nacoulma BMI, Schumann K, Traore S, Karen Hahn MB, Wittig R, Thiombiano A. 2011. Impacts of land-use on West African savanna vegetation: a comparison between protected and communal area in Burkina Faso. Biodivers Conserv, DOI 10.1007/s10531-011-0114-0

Natta AK. 2003. Ecological assessment of riparian forest in Benin. Phytodiversity, phytosociology and spatial distribution of tree species. $\mathrm{PhD}$ Thesis, Wageningen University, p. 215.

Natalie VEB. 2000. The vegetation potential of natural rangelands in the midfish river valley, Eastern Cape, South Africa: Towards a sustainable and acceptable management system. PhD Thesis, University of Rhodes, p. 111.

Orthmann B. 2005. Vegetation ecology of a woodland-savanna mosaic in central Benin (West Africa): Ecosystem analysis with a focus on the impact of selective logging. $\mathrm{PhD}$ thesis, University of Rostock, p. 117.

Ouoba P. 2006. Flore et végétation de la forêt classée de Niangoloko, Sud-Ouest du 
Burkina Faso. Thèse de doctorat, Université de Ouagadougou, p. 144.

Ouédraogo O. 2009. Phytosociologie, dynamique et productivité de la végétation du parc national d'Arly (SudEst du Burkina Faso). Thèse de doctorat, Université de of Ouagadougou, p. 140.

Oumarou M. 2003. Etudes écologique, floristique, phytogéographique et phytosociologique des inselbergs du Bénin. Thèse de doctorat, Université Libre de Bruxelles, p. 210.

Rahmatullah Q. 2008. Vegetation assessment of Sawan Wari of Nara desert, Pakistan. Pak. J. Bot., 40(5): 1885-1895.

Robert TP. 1969. The pisaster-tegula interaction: prey patches, predator food preference, and intertidal community structure. Ecology, 50(6): 950-961.

Saco PM, Willgoose GR, Hancock GR. 2007. Eco-geomorphology of banded vegetation patterns in arid and semi-arid regions. Hydrol. Earth Syst. Sci., 11: 1717-1730.

Soumana I. 2011. Groupements végétaux pâturés des parcours de la région de Zinder et stratégies d'exploitation développées par les éleveurs Uda'en.
Thèse de Doctorat de l'Université de Niamey, p. 222.

Su Y, Li Y, Cui J, Zhao W. 2005. Influences of continuous grazing and livestock exclusion on soil properties in a degraded sandy grassland, Inner Mongolia, northern China. Catena, 59: 267-278.

Timothy JK. 2007. The roles of seed mass and persistent seed banks in gap colonisation in grassland. Plant Ecol., 193: 233-239.

Togola, M. 1982. Contribution à la l'étude de la vegetation Sahelo-soudanienne et les potentialities pastorales de la region de Kaarta (Mali). Thèse de Doctorat $3^{\mathrm{e}}$ cycle de l'Université de Paris-sud, centre d'Orsay, p. 86.

Wondzell SM, Cunningham GL, Bachelet D. 1996. Relationships between landforms, geomorphic processes, and plant communities on a watershed in the northern Chihuahuan Desert. Landscape Ecology, 11(6): 351-362. 